\title{
Diets containing crude glycerin damage the sperm characteristics and modify the testis histology of Nile tilapia broodstock
}

\author{
Juliana Kasper Mewes ${ }^{\mathrm{a}, *}$, Fabio Meurer ${ }^{\mathrm{c}}$, Lucelia Tessaro ${ }^{\mathrm{b}}$, Alexandre Henrique Buzzi ${ }^{\mathrm{a}}$, \\ Mirna Adriane Syperreck ${ }^{\mathrm{d}}$, Robie Allan Bombardelli ${ }^{\mathrm{a}}$ \\ a Universidade Estadual do Oeste do Paraná - UNIOESTE, Rua da Faculdade, 645, Jardim La Salle, CEP 85903-000 Toledo, Paraná, Brazil \\ b Centro de Aquicultura, Universidade Estadual Paulista “Julio de Mesquita Filho”, Via de acesso Prof. Paulo Donato Castellane, s/n, CEP: 14884-900 Jaboticabal, São Paulo, Brazil \\ c Universidade Federal do Paraná, Rua Pioneiro, 2153, Jardim Dallas, CEP: 85950-000 Palotina, PR, Brazil \\ d Universidade Estadual de Londrina, Rodovia Celso Garcia Cid, s/n, CEP: 86057-970 Londrina, Paraná, Brazil
}

\section{A R T I C L E I N F O}

\section{Article history:}

Received 23 February 2016

Received in revised form 22 August 2016

Accepted 25 August 2016

Available online 27 August 2016

\section{Keywords:}

Biodiesel

CASA

Fecundity

Semen

Spermatozoids

Testicle

\begin{abstract}
A B S T R A C T
The effects of crude glycerin in the diets of male Nile tilapia (Oreochromis niloticus) on growth, seminal and spermatic characteristics, blood parameters, histological aspects of the hepatic and testicular tissue, and on the chemical composition of different organs/tissues were evaluated. For 10 months, the animals were fed diets containing $32 \%$ digestible protein (DP), $3200 \mathrm{kcal}$ digestible energy (DE) $\cdot \mathrm{kg}$ ration ${ }^{-1}$ and five inclusion levels of crude glycerin $(0,4,8,12$ and $16 \%)$. Growth, seminal and spermatic parameters were evaluated, and the plasmatic levels of calcium, triglycerides and glucose were measured. Gonadosomatic, viscerosomatic and hepatosomatic indexes were evaluated and combined with the histological parameters of the testicles and liver. Finally, the centesimal composition of the muscles, testis, liver and viscera were evaluated. The volume of semen released, fecundity, effective fecundity and plasmatic levels of glucose decreased proportionally $(p<0.05)$ to the increase of glycerin in the diet. The hepatosomatic index increased proportionally $(p<0.05)$ to the inclusion levels of crude glycerin in the diet. Fish fed on glycerin had the highest protein levels $(p<0.05)$ in the muscle and testicles. Histological assessment suggests that fish fed the lowest glycerin diet had the highest amounts of spermatozoids in the testicles. Other variables under analysis were not affected by diet $(p>0.05)$. The results show that, although crude glycerin does not impair growth, any inclusion level in the diet impairs the spermatogenesis process and damages the sperm characteristics of male Nile tilapia.

Statement of relevance: Do not use the crude glycerin to the Nile tilapia males.
\end{abstract}

(c) 2016 Elsevier B.V. All rights reserved.

\section{Introduction}

The breeding of Nile tilapia has become one of the main components of aquaculture worldwide. With a global production of approximately 3.95 million tons in 2011, it ranks second in fresh water fish (FAO, 2014).

The continuous supply of eggs, larvae and fries (both in quality and quantity) is highly relevant to supporting the high rates of tilapia culture growth (El-Sayed, 2006). In this context, studies examining the nutrition and feeding of broodstock (Hardy, 1999; Watanabe et al., 2002) are important because the diet affects the endocrine system, and consequently the reproduction performance of the fish (Watanabe and Vassalo-Agius, 2003), jeopardizing the fecundity (Bromage, 1995;

\footnotetext{
* Corresponding author.

E-mail addresses: julimewes@gmail.com (J.K. Mewes), fabio_meurer@yahoo.com.br (F. Meurer), luceliatessaro@gmail.com (L. Tessaro), alexandre.hbuzzi@gmail.com (A.H. Buzzi), msyperreck@hotmail.com (M.A. Syperreck), rabombardelli@gmail.com (R.A. Bombardelli).
}

Tyler and Sumpter, 1996) and the quality of gametes, embryos and larvae (Izquierdo et al., 2001). Scanty information exists on the nutrition of broodstock and fish matrixes (Bombardelli et al., 2009), and the majority focuses on females (El-Sayed et al., 2005; Ng and Wang, 2011; Oliveira et al., 2014) with little attention to the males. While it has been widely reported that diet can interfere with the quality of fresh semen and spermatozoa in the same way that it can affect the quality and the viability of spermatozoids after cryopreservation (Putstowka et al., 2000), information on the effects of diet on male reproduction in tilapia broodstock is exceedingly rare. The few extant results on the issue suggest that vitamin C supplementation in the diet improves the quality of spermatozoids (Mataveli et al., 2007) and that the levels of digestible energy in the diet affect spermatogenesis. In fact, diets with approximately $3450 \mathrm{kcal}$ of $\mathrm{ED} \cdot \mathrm{kg}$ of diet $^{-1}$ result in higher sperm concentrations and higher percentages of spermatozoids without any morphological changes (Bombardelli et al., 2010). Studies regarding feed resources that would trigger growth and reproduction should be undertaken by researchers in animal nutrition.

Byproducts or agro-industrial byproducts are highlighted due to their potential as alternative and low cost ingredients. Due to recent 
interest in the search for renewable energy sources, great importance has been given to the biodiesel industry (Ayoub and Abdullah, 2012), especially with regard to crude glycerin, which corresponds to $10 \%$ of biodiesel production (Swiatkiewicz and Koreleski, 2009). Glycerin is an ingredient with feed potential because it is mainly comprised of glycerol, which plays an important role in energy metabolism (Lin, 1977).

Crude glycerin has been successfully employed in swine (Shields et al., 2011; Berenchtein et al., 2010) and broiler chicken (Kroupa et al., 2011) feed. Glycerin may be highly useful in tilapia because it has a digestible energy (DE) similar to corn, corresponding to $3126.5 \mathrm{kcal}$ $\mathrm{DE} \cdot \mathrm{kg}^{-1}$ (Meurer et al., 2012) or $2875.8 \mathrm{kcal} \mathrm{DE} \cdot \mathrm{kg}^{-1}$ (Gonçalves et al., 2015). Research suggests that diets containing up to $10 \%$ crude glycerin do not affect the growth of channel catfish (Ictalurus punctatus) (Li et al., 2010) and Nile tilapia fingerlings (Neu et al., 2012). A recent study showed that diets containing up to $12 \%$ crude glycerin did not alter the performance of Nile tilapia juveniles (Gonçalves et al., 2015). The results suggest that crude glycerin may be able to replace corn in these diets.

The current assay evaluates the effects of the inclusion of crude glycerin in the diet of Nile tilapia broodstock (O. niloticus) on growth, seminal and sperm characteristics, blood parameters, histological aspects of the hepatic and testicular tissues and on the chemical composition of different organs/tissues.

\section{Materials and methods}

\subsection{Animals, installations and experimental design}

The current study complied with the requirements of the Committee for Ethics in Animals of the Universidade Estadual do Oeste do Paraná (CEUA/Unioeste), according to protocol 03212-CEUA/Unioeste. Four hundred females $(25.73 \pm 0.11 \mathrm{~g})$ and 200 males $(25 \pm 0.43 \mathrm{~g})$ of the GIFT strain of $O$. niloticus were used during the first maturation age. The females and males were separately penned in forty $1-\mathrm{mm}$ mesh hapas. The hapas were installed in a brick tank with an earthen floor. While females were stocked into twenty $3 \mathrm{~m} \times 2 \mathrm{~m}$ hapas at 20 females per hapa, the males were stocked into twenty $2 \mathrm{~m} \times 1 \mathrm{~m}$ hapas at 10 males per hapa. All broodstock were marked by electronic markers implanted under the skin. Marks featured ISO FDX-B $134.2 \mathrm{kHz}$ and an external antimigration layer.

The animals were distributed in a totally randomized experimental design with five treatments and four replications. The treatments were comprised of iso-protein and iso-energy diets with $32 \%$ digestible protein (DP) and $3200 \mathrm{kcal}$ of digestible energy (DE) $\cdot \mathrm{kg}$ of diet ${ }^{-1}$ and five inclusion levels of crude glycerin at $0,4,8,12$ and $16 \%$ of diet dry weight.

\subsection{Experimental diet, feed management and reproduction management}

Ingredients were evaluated for their nutritional composition prior to diet formulation. The diets were formulated to contain $32 \% \mathrm{DP}$ and $3200 \mathrm{kcal} \mathrm{DE} \cdot \mathrm{kg} \mathrm{diet}{ }^{-1}$ (Table 1). The digestibility coefficients of the ingredients (Boscolo et al., 2002; Meurer et al., 2003; Meurer et al., 2012) were used to calculate the digestible protein and digestible energy of the rations. The ingredients were ground in a hammer mill, passed through a $0.5-\mathrm{mm}$ sieve and mixed. Next, heated water at $60{ }^{\circ} \mathrm{C}$ was added, and the ingredients were pelleted (3-mm diameter) to produce a sinking ration. Finally, the pelleted ration was dried at $55^{\circ} \mathrm{C}$ in a stove with forced ventilation.

The fish were fed twice a day (10:00 h and 16:00 h) over 10 months (Siddiqui et al., 1998; El-Sayed et al., 2005) at a feed rate of $1 \%$ biomass per day (Bhujel, 2000), adjusted every 17 days. The fish were submitted to reproduction management during this period, with the males and females separated for a 12-day period (adapted Tacon et al., 1996; Bombardelli et al., 2009). After this period, the males were transferred to the hapas with females for mating for five days (adapted Macintosh
Table 1

Composition of feed and nutrient contents (\%) of experimental diets at different inclusion levels of crude glycerin used in the feed of matrixes and broodstock of the Nile tilapia $(0$. niloticus).

\begin{tabular}{|c|c|c|c|c|c|}
\hline \multirow[t]{2}{*}{ Ingredients (\%) } & \multicolumn{5}{|c|}{ Crude glycerin (\%) } \\
\hline & 0 & 4 & 8 & 12 & 16 \\
\hline Soy meal ${ }^{\mathrm{a}}$ & 62.58 & 63.53 & 64.48 & 65.43 & 66.37 \\
\hline Corn $^{a}$ & 24.05 & 19.19 & 14.33 & 9.47 & 4.61 \\
\hline Fish flour ${ }^{\mathrm{b}}$ & 5.00 & 5.00 & 5.00 & 5.00 & 5.00 \\
\hline Soy oil ${ }^{\mathrm{a}}$ & 4.41 & 4.29 & 4.17 & 4.05 & 3.93 \\
\hline Salt & 0.50 & 0.50 & 0.50 & 0.50 & 0.50 \\
\hline Bi-calcium phosphate & 2.44 & 2.48 & 2.51 & 2.54 & 2.58 \\
\hline Crude glycerin ${ }^{\mathrm{C}}$ & 0.00 & 4.00 & 8.00 & 12.00 & 16.00 \\
\hline Mineral and vitamin suppl ${ }^{\mathrm{d}}$ & 1.00 & 1.00 & 1.00 & 1.00 & 1.00 \\
\hline Antioxidant ${ }^{\mathrm{e}}$ & 0.01 & 0.01 & 0.01 & 0.01 & 0.01 \\
\hline \multicolumn{6}{|l|}{ Nutrients ${ }^{\mathrm{f}}$} \\
\hline Calcium (\%) & 1.04 & 1.05 & 1.06 & 1.07 & 1.08 \\
\hline Methionine + cystine (\%) & 1.01 & 1.00 & 1.00 & 0.99 & 0.99 \\
\hline Crude energy $\left(\mathrm{kcal} \cdot \mathrm{kg}^{-1}\right)$ & 4250.26 & 4232.34 & 4214.41 & 4196.48 & 4178.56 \\
\hline Digestible energy $\left(\mathrm{kcal} \cdot \mathrm{kg}^{-1}\right)$ & 3200.00 & 3200.00 & 3200.00 & 3200.00 & 3200.00 \\
\hline Crude fiber $(\%)$ & 2.60 & 2.37 & 2.14 & 1.91 & 1.69 \\
\hline Total phosphorus (\%) & 1.00 & 1.00 & 1.00 & 1.00 & 1.00 \\
\hline Fat $(\%)$ & 6.41 & 6.17 & 5.94 & 5.71 & 5.47 \\
\hline Crude protein (\%) & 35.70 & 35.72 & 35.74 & 35.76 & 35.78 \\
\hline Digestible protein (\%) & 32.00 & 32.00 & 32.00 & 32.00 & 32.00 \\
\hline
\end{tabular}

a Digestibility rates of nutrients according to Boscolo et al. (2002).

b Digestibility rates of nutrients according to Meurer et al. (2003).

c Digestibility rates of nutrients according to Meurer et al. (2012).

d Mineral and vitamin supplementation, basal composition: folic acid: $200 \mathrm{mg}$; pantothenic acid: $4.000 \mathrm{mg}$; Biotin: $40 \mathrm{mg}$; Copper: $2.000 \mathrm{mg}$; Iron: $12.500 \mathrm{mg}$; Iodine: $200 \mathrm{mg}$; Manganese: $7.500 \mathrm{mg}$; Niacin: $5.000 \mathrm{mg}$; Selenium: $70 \mathrm{mg}$; Vitamin A: 1.000.000 UI; Vitamin B1: $1.900 \mathrm{mg}$; Vitamin B12: $3.500 \mathrm{mg}$; Vitamin B2: $2.000 \mathrm{mg}$; Vitamin B6: 2.400 mg; Vitamin C: 50.000 mg; Vitamin D3: 500.000 UI; Vitamin E: 20.000 UI; Vitamin K3: $500 \mathrm{mg}$; Zinc: $25.000 \mathrm{mg}$.

e Propionic acid.

f The nutrient contents were calculated using Super Crac Premium ${ }^{\circledR}$ software.

and Little, 1995; Bombardelli et al., 2009). These procedures were used to maintain all males in reproductive activity and mating.

At the end of the mating period, the fish were weighed using a digital scale (Marte ${ }^{\circledR}$ AS2000; $0.01 \mathrm{~g}$ ) and measured individually by a precision ichthyometer $(0.1 \mathrm{~cm})$. Then, the males and females were separated once more in their hapas for another period of isolated rearing. The same procedure was repeated during the entire experimental period.

\subsection{Monitoring the physical and chemical parameters of water}

The minimum $\left(25.39 \pm 1.85^{\circ} \mathrm{C}\right)$ and maximum $\left(28.22 \pm 2.06{ }^{\circ} \mathrm{C}\right)$ temperatures in the earthen tanks were measured daily (at $10 \mathrm{~h}$ ) using a max-min mercury thermometer $\left( \pm 1{ }^{\circ} \mathrm{C}\right)$. Dissolved oxygen $\left(6.49 \pm 1.48 \mathrm{mg} \cdot \mathrm{L}^{-1}\right.$; Oximeter YSI $\left.{ }^{8} 550 \mathrm{~A}\right)$ and water $\mathrm{pH}(8.01 \pm$ 0.48 ; digital $\mathrm{pH}$ meter Tecnal ${ }^{\circledR}$ Tec 5 ) were both measured at $6 \mathrm{~h}$ fortnightly.

\subsection{Seminal and spermatic parameters}

In December, after the isolated rearing period and prior to mating, five males of each experimental unit were randomly selected and anaesthetized using a solution of $100 \mathrm{mg}$ benzocaine hydroxide $\cdot \mathrm{L}^{-1}$. The fish were weighed and measured, and their semen was collected for assessment of seminal and spermatozoid counts.

The semen was collected by abdominal massage applied in a cephalic-caudal direction. The first drop of semen was discarded to avoid possible contamination with urine, mucus and feces (Khara et al., 2012). The total volume of semen provided by each male was measured in $1.0 \mathrm{~mL}$ syringes, with a precision of $0.01 \mathrm{~mL}$ (adapted to Sanches et al., 2013). Seminal pH was immediately measured after collection using the colorimeter method with litmus paper (Merck ${ }^{\circledR}$ ) (Tessaro et al., 2012). After collection, the semen was kept under refrigeration $\left( \pm 12{ }^{\circ} \mathrm{C}\right)$ until seminal and spermatic analyses (Kanuga et al., 2012). 
The semen samples were evaluated with regard to spermatic variables using the CASA plugin (Adames et al., 2015) adapted to the species (Entrance rates of plug-in CASA; $\mathrm{a}=1, \mathrm{~b}=30, \mathrm{c}=100, \mathrm{~d}=8, \mathrm{e}=1$, $\mathrm{f}=10, \mathrm{~g}=15, \mathrm{~h}=3, \mathrm{i}=1, \mathrm{j}=25, \mathrm{k}=10, \mathrm{l}=15, \mathrm{~m}=80, \mathrm{n}=80, \mathrm{o}=$ $50, p=60, q=100, r=943.3962$; capture rate 100 fs; magnifying objective $10 \times$; Neubauer camera). The motility rates of the spermatozoids and the curvilinear velocity (CLV), mean displacement velocity (MDV) and straight line velocity (SLV) were evaluated. Assessments were performed $15 \mathrm{~s}$ after the start of spermatic activation by $1 \mathrm{~s}$ images in a $10 \times$ magnifying objective (Adames et al., 2015). Due to a high co-relationship between spermatic velocities provided by the CASA plugin $(r=$ $0.92 ; r=0.98 ; r=0.96$ ), the results of the three velocities were grouped by the Principal Components Analysis (PCA), which generated a new variable called spermatic velocity (Tessaro et al., 2012), featuring 30.93\% CLV, 35.25\% MDV and 33.82\% SLV. The period in which spermatozoids remained in movement was also measured (Adames et al., 2015). Spermatic activation was performed in Eppendorf tubes ( $1.5 \mathrm{~mL}$ ), with $1 \mu \mathrm{L}$ semen and $800 \mu \mathrm{L}$ of the activating solution (distilled water).

A $5 \mu \mathrm{L}$ semen sample from each male was fixed in $5000 \mu \mathrm{L}$ buffered saline formaldehyde to measure spermatic concentration and the spermatozoid index with morphological alterations (Tessaro et al., 2012). The spermatozoid index with morphological alterations was determined by diluting $40 \mu \mathrm{L}$ of semen previously fixed in $2 \mu \mathrm{L}$ Rose Bengal staining solution. Next, $20 \mu \mathrm{L}$ of stained semen were placed on airdried lamina and covered with a cover slip for later analysis under a $40 \times$ optic microscope. Approximately 300 spermatozoids were counted and classified as normal or abnormal (Rurangwa et al., 2004). Spermatic concentration was determined by the spermatic cell count using the Neubauer hematimetric camera (Wirtz and Steinmann, 2006). Then, the fecundity and effective fecundity were calculated according to the equations below:

Fecundity $=$ Volumex $\times$ Concentration

Effective fecundity $=$ Volumex $\times$ Concentration $\times$ Motility,

where

Fecundity = number of spermatozoids provided by the male;

Effective fecundity = number of movable spermatozoids provided by the male;

Volume $=$ volume of provided semen $(\mathrm{mL})$;

Concentration $=$ spermatic concentration in provided semen (spermatozoids $\cdot \mathrm{mL}^{-1}$ );

Motility $=$ percentage of movable spermatic cells (\%).

\subsection{Growth parameters, blood parameters and body indexes}

After seminal and spermatic evaluation, the broodstock were reared separated by sex as previously described. In January, five males from each hapa were anaesthetized with a solution of $100 \mathrm{mg}$ benzocaine hydroxide $\cdot \mathrm{L}^{-1}$ and the fish were weighed and measured individually. These males were submitted to blood collection by caudal vein puncture, with the tip of the needle inserted perpendicularly into the caudal vein, below the lateral line (Tavares-Dias and Moraes, 2004). Furthermore, at least $2 \mathrm{~mL}$ of blood was collected from each fish. The samples were centrifuged at $3200 \mathrm{rpm}$ for $10 \mathrm{~min}$ and processed for the quantification of calcium, triglycerides and plasma glucose levels using the enzymatic-colorimeter method (Laborclin $₫$ ) with spectrophotometer (Bel Photonics® SF 325NM), according to Neu et al. (2012).

All males from each experimental unit were then anaesthetized and euthanized by immersion in a solution with $250 \mathrm{mg}$ benzocaine hydroxide $\cdot \mathrm{L}^{-1}$ and by displacement of the cervical column, respectively. The euthanized males were dissected to determine the weight of the liver, gonads and viscera. The hepatosomatic index (Bombardelli et al.,
2010), gonadosomatic index (Vazzoler, 1996) and viscerosomatic index (Ng and Wang, 2011) were assessed from these data.

The calculation of the variables including mean weight gain, apparent food conversion and condition factor was based on weight and length results obtained from biometry every 17 days.

\subsection{Histology of testicles and liver}

Five livers and five testicles were randomly chosen from each experimental unit for morphological evaluation. The organs were placed in a Bouin solution for $24 \mathrm{~h}$ and then transferred to a $70 \%$ alcohol solution. The material was dehydrated by passing it through several increasing alcohol series, and it was included in histological resins. Next, $3 \mu \mathrm{m}$ thick transversal cuts were removed from the testicles and stained with hematoxylin and eosin. Laminas were mounted on Permont ${ }^{\circ}$, evaluated and photographed under optic microscope (Olympus CX31) with a digital camera (Olympus SC30). The stages of testicle development and reproduction phases of the males were assessed (BrownPeterson et al., 2011).

Similarly, $4 \mu \mathrm{m}$-thick liver samples were processed, stained and photographed. The hepatic vacuolization score was employed to evaluate the liver (Caballero et al., 2004, with modifications), with rates between 0 and 3 for the presence of vacuoles: Score $0=$ lack of vacuoles; Score $1=$ reduced vacuolization; Score $2=$ intermediate vacuolization; Score 3 = intense vacuolization. Morphometric evaluations of the hepatic tissue were undertaken by images of random fields at $400 \times$ magnification. The maximum, minimum and mean areas of 200 hepatocytes of each liver were measured. Areas adjacent to the central lobular veins were selected as the standard site. Images were analyzed by ImagePro-plus ${ }^{\circledR}$ (Tessaro et al., 2012, modified).

\subsection{Chemical composition of body tissues}

Samples of muscle, viscera, liver and testicle tissues were then stored at $-20^{\circ} \mathrm{C}$ for later analysis of their chemical composition, following the procedures of Mizubuti et al. (2009, adapted). The crude protein, ether extract, humidity and ash concentrations of muscle samples were evaluated. Due to the small volumes of the samples, ether extract and crude protein rates were evaluated for the liver and gonads, respectively. Only the ether extract and crude protein of the viscera were evaluated.

\subsection{Statistical analyses}

The results underwent analysis of variance at a 5\% significance level. The variables of growth, seminal and spermatic, somatic index, plasmatic, testicular and hepatic parameters underwent regression analysis. Due to the lack of regression model adjustment and to the existence of treatment effects on the chemical composition variables of the different organs/tissues, results were analyzed by Tukey's mean multiple comparison test. Normality and homoscedasticity presuppositions were checked. Indexes in percentage underwent arcsine square root transformation. The velocity data (CLV, MDV, and SLV) underwent PCA and was then co-related. When a co-relationship was extant, a common factor was generated and submitted to analysis of variance, similar to the other parameters. Statistica $7.0 \odot$ was used for the procedures and statistical analyses.

\section{Results}

The physical and chemical parameters of the water did not vary between the experimental units $(p>0.05)$.

Diets with different crude glycerin inclusion levels impaired the spermatogenesis and affected the sperm characteristics. The volume of semen provided, fecundity and effective fecundity decreased in direct proportion $(p<0.05)$ to the increase in crude glycerin in the diets 
Table 2

Seminal and spermatic parameters in Nile tilapia males (O. niloticus) fed diets with different levels of crude glycerin.

\begin{tabular}{|c|c|c|c|c|c|c|}
\hline \multirow[t]{2}{*}{ Variable } & \multicolumn{5}{|c|}{ Inclusion level of crude glycerin (\%) } & \multirow[t]{2}{*}{$p$} \\
\hline & 0 & 4 & 8 & 12 & 16 & \\
\hline $\mathrm{VS}(\mathrm{mL})^{\mathrm{a}}$ & $0.14 \pm 0.04$ & $0.09 \pm 0.06$ & $0.04 \pm 0.02$ & $0.06 \pm 0.07$ & $0.05 \pm 0.07$ & 0.0322 \\
\hline $\mathrm{pH}$ & $6.29 \pm 0.34$ & $6.67 \pm 0.58$ & $6.17 \pm 0.29$ & $6.00 \pm 0.00$ & $6.50 \pm 0.50$ & 0.3073 \\
\hline AT $(s)$ & $111.93 \pm 16.67$ & $104.40 \pm 5.22$ & $111.56 \pm 8.83$ & $121.25 \pm 10.11$ & $119.38 \pm 14.36$ & 0.3960 \\
\hline Mot $(\%)$ & $80.00 \pm 0.05$ & $69.00 \pm 0.21$ & $77.00 \pm 0.02$ & $77.00 \pm 0.17$ & $78.00 \pm 0.05$ & 0.8691 \\
\hline $\mathrm{SV}\left(\mathrm{um} \cdot \mathrm{s}^{-1}\right)$ & $68.12 \pm 11.98$ & $55.45 \pm 9.47$ & $58.37 \pm 5.24$ & $64.29 \pm 3.74$ & $61.74 \pm 5.71$ & 0.2608 \\
\hline $\operatorname{CSV}\left(\mathrm{um} \cdot \mathrm{s}^{-1}\right)$ & $98.61 \pm 12.34$ & $84.77 \pm 13.45$ & $87.94 \pm 4.46$ & $98.59 \pm 6.83$ & $91.33 \pm 6.75$ & 0.2034 \\
\hline $\operatorname{MSV}\left(\mathrm{um} \cdot \mathrm{s}^{-1}\right)$ & $57.27 \pm 12.65$ & $44.96 \pm 8.55$ & $47.27 \pm 5.56$ & $51.69 \pm 3.18$ & $50.81 \pm 5.60$ & 0.2817 \\
\hline $\operatorname{SLV}\left(\mathrm{um} \cdot \mathrm{s}^{-1}\right)$ & $51.70 \pm 11.97$ & $39.73 \pm 7.60$ & $43.07 \pm 5.64$ & $46.24 \pm 3.17$ & $46.23 \pm 5.12$ & 0.2880 \\
\hline Norm (\%) & $59.36 \pm 6.76$ & $60.06 \pm 7.36$ & $57.20 \pm 2.42$ & $59.31 \pm 4.89$ & $63.08 \pm 3.77$ & 0.4003 \\
\hline CSPZ & $3.37 \pm 2.01 \times 10^{9}$ & $3.30 \pm 3.66 \times 10^{9}$ & $2.99 \pm 2.23 \times 10^{9}$ & $1.12 \pm 0.26 \times 10^{9}$ & $1.82 \pm 1.74 \times 10^{9}$ & 0.4545 \\
\hline Fecundity $^{\mathrm{b}}$ & $5.24 \pm 4.68 \times 10^{8}$ & $1.13 \pm 0.77 \times 10^{8}$ & $1.35 \pm 1.21 \times 10^{8}$ & $0.57 \pm 0.57 \times 10^{8}$ & $0.38 \pm 0.44 \times 10^{8}$ & 0.0028 \\
\hline Effective fecundity ${ }^{c}$ & $4.20 \pm 3.87 \times 10^{8}$ & $0.77 \pm 0.54 \times 10^{8}$ & $1.07 \pm 0.97 \times 10^{8}$ & $0.47 \pm 0.47 \times 10^{8}$ & $0.30 \pm 0.37 \times 10^{8}$ & 0.0039 \\
\hline
\end{tabular}

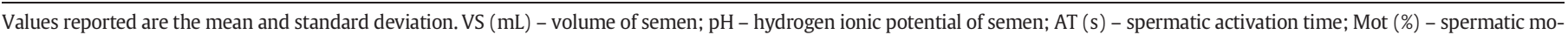

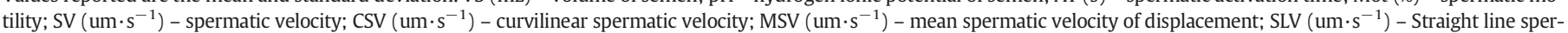
matic velocity; Norm (\%) - spermatic normality; CSPZ - spermatic concentration; Fecundity (number of spermatozoids); Effective fecundity (number of motile spermatozoids).

a $y=0.1171-0.0051 x, \mathrm{r}=0.4923$.

b $y=12.7273-0.0004 x, \mathrm{r}=0.6314$.

c $y=12.526-0.0005 x, \mathrm{r}=0.6153$.

Table 3

Plasma parameters in Nile tilapia males (O. niloticus) fed diets with different levels of crude glycerin.

\begin{tabular}{|c|c|c|c|c|c|c|}
\hline \multirow[t]{2}{*}{ Variables } & \multicolumn{5}{|c|}{ Inclusion level of crude glycerin (\%) } & \multirow[t]{2}{*}{$p$} \\
\hline & 0 & 4 & 8 & 12 & 16 & \\
\hline Glucose $^{\mathrm{a}}\left(\mathrm{mg} \cdot \mathrm{dL}^{-1}\right)$ & $112.48 \pm 47.66$ & $103.88 \pm 23.37$ & $102.80 \pm 26.27$ & $78.71 \pm 28.50$ & $72.52 \pm 29.02$ & 0.0432 \\
\hline Calcium $\left(\mathrm{mg} \cdot \mathrm{dL}^{-1}\right)$ & $8.40 \pm 1.69$ & $8.28 \pm 2.81$ & $10.05 \pm 4.32$ & $6.47 \pm 2.54$ & $6.47 \pm 1.25$ & 0.3466 \\
\hline Triglycerides $\left(\mathrm{mg} \cdot \mathrm{dL}^{-1}\right)$ & $161.74 \pm 37.00$ & $157.36 \pm 75.60$ & $134.94 \pm 51.22$ & $158.49 \pm 49.34$ & $134.98 \pm 117.40$ & 0.9664 \\
\hline
\end{tabular}

Values reported are the mean and standard deviation.

a $y=115.1692-2.632 x, \mathrm{r}=0.4683$.

(Table 2 ). The other seminal and spermatic parameters were not affected $(p>0.05)$ by diet (Table 2$)$.

The feeding of males with diets containing crude glycerin affected the plasma glucose levels. The plasma glucose levels decreased $(112.48 \pm 47.66$ to $72.52 \pm 29.02 \mathrm{mg} / \mathrm{dL})$ in direct proportion $(p<0.05)$ to the increase in crude glycerin in the diets (Table 3$)$. Calcium and plasma triglyceride levels were not affected by diet (Table 3 ).

The growth of the tilapia was not affected $(p>0.05)$ by diets with different levels of crude glycerin (Table 4 ). Weight gain ranged between $153.60 \pm 11.21$ and $170.46 \pm 5.47 \mathrm{~g}$, with male survival at $100 \%$.
Although feed conversion was not changed by diets, rates were high and ranged between $1.91 \pm 0.07$ and $2.21 \pm 0.25$. The condition factor remained between $76.17 \pm 12.18$ and $101.83 \pm 31.31$ (Table 4).

Only the hepatosomatic index within the context of body indexes increased proportionally $(p<0.05)$ to an increase in crude glycerin in the diets (Table 5). Gonadosomatic and viscerosomatic indexes were not affected $(p>0.05)$ by diets containing crude glycerin (Table 5).

The histological assessment of the gonads revealed differentiation cysts (spermatogonia, spermatocytes, spermatids and spermatozoids) in all treatments, although a greater quantity of spermatozoids in the

Table 4

Animal performance parameters of Nile tilapia males (O. niloticus) fed diets with different levels of crude glycerin.

\begin{tabular}{|c|c|c|c|c|c|c|}
\hline \multirow[t]{2}{*}{ Variables } & \multicolumn{5}{|c|}{ Inclusion level of crude glycerin (\%) } & \multirow[t]{2}{*}{$p$} \\
\hline & 0 & 4 & 8 & 12 & 16 & \\
\hline \multicolumn{7}{|l|}{ Males } \\
\hline IMW (g) & $25.67 \pm 0.44$ & $25.53 \pm 0.10$ & $25.81 \pm 0.15$ & $25.79 \pm 0.18$ & $25.83 \pm 0.29$ & 0.4728 \\
\hline FMW (g) & $196.13 \pm 5.34$ & $180.46 \pm 19.33$ & $190.03 \pm 8.80$ & $179.39 \pm 11.04$ & $184.14 \pm 10.56$ & 0.2883 \\
\hline WG (g) & $170.46 \pm 5.47$ & $154.93 \pm 19.25$ & $164.22 \pm 8.69$ & $153.60 \pm 11.21$ & $158.31 \pm 10.72$ & 0.2913 \\
\hline FC & $2.21 \pm 0.25$ & $2.15 \pm 0.40$ & $2.14 \pm 0.28$ & $1.91 \pm 0.07$ & $2.03 \pm 0.23$ & 0.5459 \\
\hline SUR (\%) & $100.00 \pm 0$ & $100.00 \pm 0$ & $100.00 \pm 0$ & $100.00 \pm 0$ & $100.00 \pm 0$ & - \\
\hline $\mathrm{CF}$ & $86.03 \pm 9.87$ & $82.35 \pm 4.93$ & $91.38 \pm 17.22$ & $76.17 \pm 12.18$ & $101.83 \pm 31.31$ & 0.3436 \\
\hline
\end{tabular}

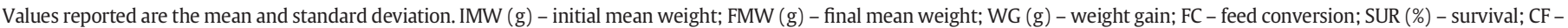
condition factor.

Table 5

Body indexes of Nile tilapia males ( 0 . niloticus) fed diets with different levels of crude glycerin.

\begin{tabular}{|c|c|c|c|c|c|c|}
\hline \multirow[t]{2}{*}{ Variables (\%) } & \multicolumn{5}{|c|}{ Inclusion level of crude glycerin (\%) } & \multirow[t]{2}{*}{$p$} \\
\hline & 0 & 4 & 8 & 12 & 16 & \\
\hline Gonadosomatic index & $0.64 \pm 0.33$ & $0.59 \pm 0.18$ & $0.66 \pm 0.27$ & $0.69 \pm 0.20$ & $0.54 \pm 0.10$ & 0.9227 \\
\hline Hepatosomatic index ${ }^{a}$ & $0.78 \pm 0.06$ & $0.82 \pm 0.02$ & $0.84 \pm 0.11$ & $0.88 \pm 0.04$ & $0.86 \pm 0.05$ & 0.0381 \\
\hline Viscerosomatic index & $5.98 \pm 2.17$ & $5.64 \pm 2.39$ & $6.36 \pm 1.48$ & $5.64 \pm 1.05$ & $5.48 \pm 1.05$ & 0.9442 \\
\hline
\end{tabular}

Values reported are the mean and standard deviation.

a $y=0.089+0.0003 x ; \mathrm{r}=0.4786$. 

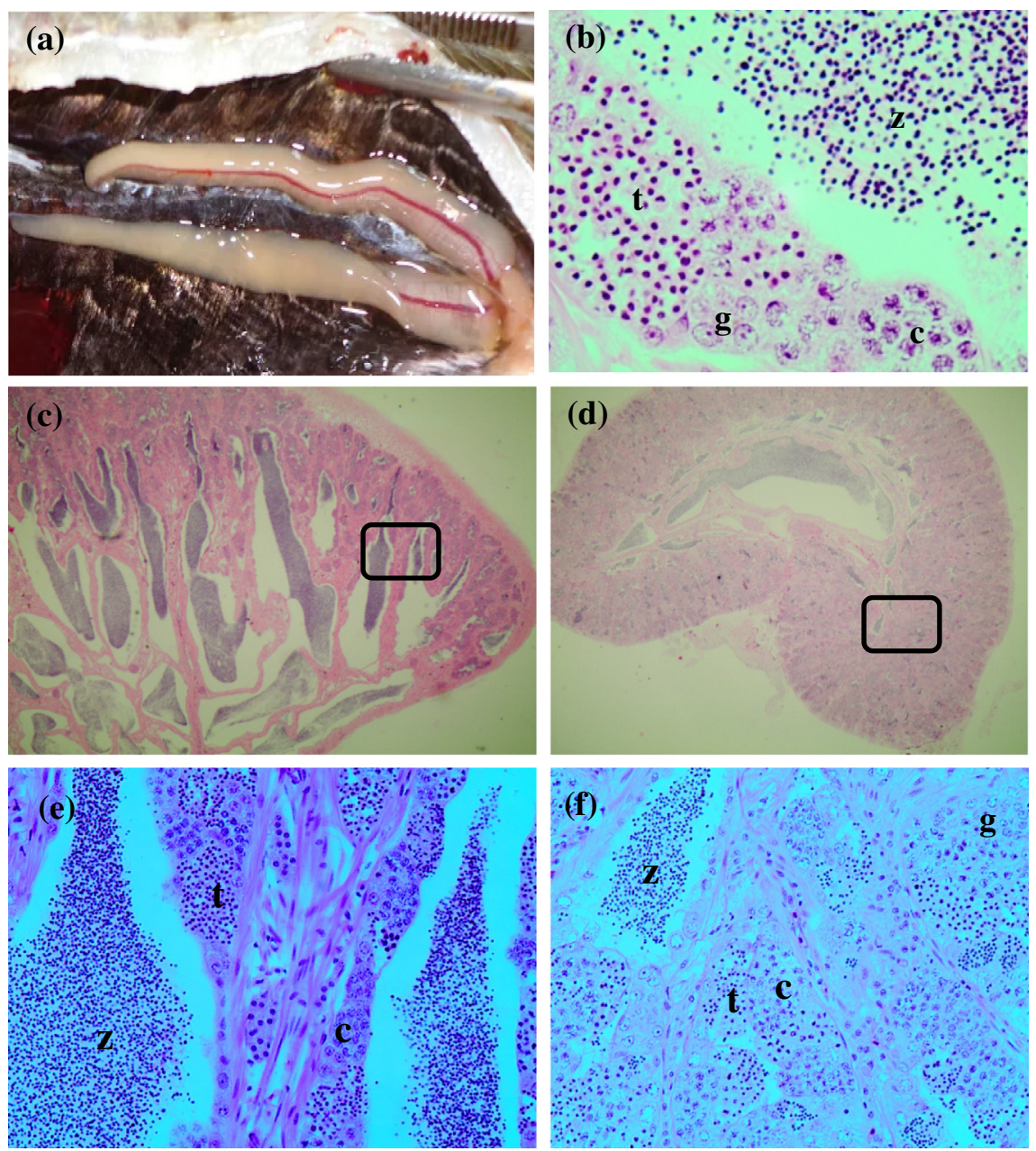

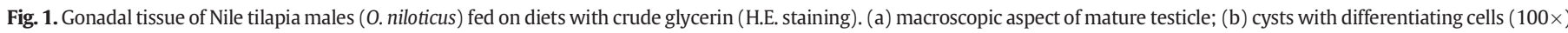

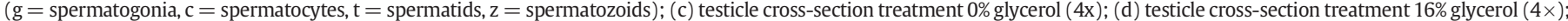

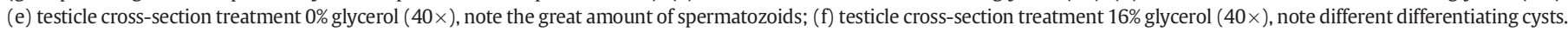

testicles of tilapia fed diets with low inclusion levels of crude glycerin was verified. The opposite was verified in treatments with higher inclusion levels (Fig. 1).

Hepatocytes' maximum, minimum and mean areas and vacuolization score were not affected $(p>0.05)$ by diet (Table 6$)$. The morphology of the hepatic tissue was characterized by irregular-form hepatocytes with the rounded nucleus in the central region. Sinusoidtype capillaries permeating the hepatocytes were also detected, coupled to veins and arteries (Fig. 2).

Tilapia males fed diets containing $>8 \%$ crude glycerin had higher crude protein rates $(p<0.05)$ in the muscle tissue (Table 7). Similarly, fish fed diets with any crude glycerin inclusion level had higher rates of crude protein $(p<0.05)$ in the testicles (Table 7$)$. The other parameters related to the chemical composition of the several organs/tissues were not affected $(p>0.05)$ by crude glycerin rates in the diets.

\section{Discussion}

Maximum and minimum water temperatures remained within the limits recommended by tilapia breeders (Bhujel, 2000). Levels of dissolved oxygen were within adequate concentrations for the reproduction of females (Bhujel, 2000), even though no studies exist regarding whether rates for males correspond to those for females (Bombardelli et al., 2010). The proper $\mathrm{pH}$ band for broodstock remains to be defined, although it remains within the parameters for fish production (ElSayed, 2006).

Crude glycerin somehow decreased semen volume, fecundity and effective fecundity of broodstock. According to Igdoura and Wiebe (1994), the main issue may lie in the inhibition of lactate synthesis in Sertoli cells, the main substrate for spermatogenesis in rats, or the hyperosmotic effects of glycerol and the degeneration of joints between

Table 6

Area and degree of vacuolization of hepatocytes of Nile tilapia males (O. niloticus) fed diets with different crude glycerin levels.

\begin{tabular}{|c|c|c|c|c|c|c|}
\hline \multirow[t]{2}{*}{ Variable } & \multicolumn{5}{|c|}{ Inclusion level of crude glycerin (\%) } & \multirow[t]{2}{*}{$p$} \\
\hline & 0 & 4 & 8 & 12 & 16 & \\
\hline $\mathrm{IA}\left(\mu \mathrm{m}^{2}\right)$ & $218.76 \pm 64.76$ & $211.19 \pm 71.78$ & $243.02 \pm 37.75$ & $149.78 \pm 41.03$ & $205.15 \pm 97.76$ & 0.4219 \\
\hline $\operatorname{MnA}\left(\mu \mathrm{m}^{2}\right)$ & $126.23 \pm 85.32$ & $123.97 \pm 88.55$ & $168.65 \pm 38.96$ & $64.06 \pm 75.44$ & $120.76 \pm 96.19$ & 0.6926 \\
\hline $\operatorname{MxA}\left(\mu \mathrm{m}^{2}\right)$ & $307.82 \pm 83.49$ & $302.87 \pm 105.58$ & $359.1 \pm 20.09$ & $227.79 \pm 49.03$ & $279.61 \pm 142.58$ & 0.3857 \\
\hline$V^{a}$ & $1(100 \%)$ & $0(25 \%) .1(25 \%) .2(50 \%)$ & $0(50 \%) \cdot 1(25 \%) \cdot 2(25 \%)$ & $0(25 \%) \cdot 1(25 \%) \cdot 2(50 \%)$ & $0(50 \%) \cdot 1(25 \%) \cdot 2(25 \%)$ & - \\
\hline
\end{tabular}

Values reported are the mean and standard deviation. IA - intermediate area; MnA - minimum area; MxA - maximum area; VD - vacuolization degree.

a $0=$ not observed; $1=$ reduced; $2=$ intermediary; $3=$ intense. 

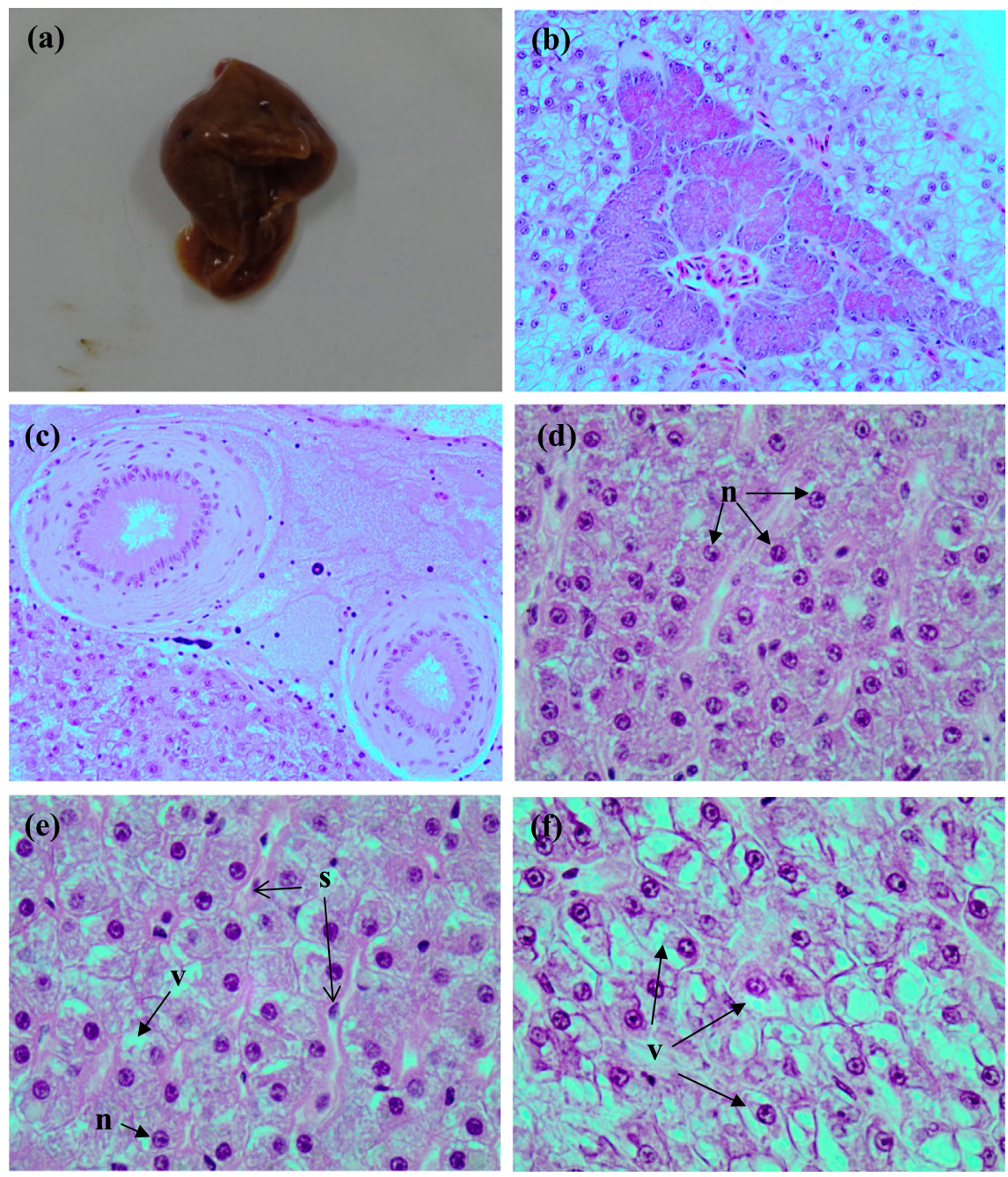

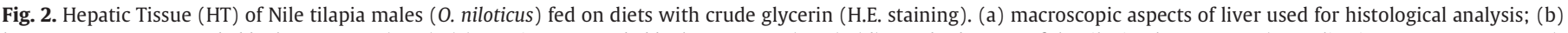

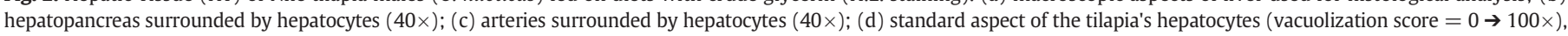

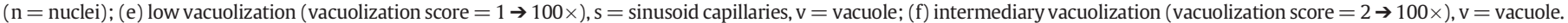

the Sertoli cells. According to Wiebe et al. (2000), the negative effects of glycerol injection in rats manifest $24 \mathrm{~h}$ after the injection and manifested as alterations in the F-actin and occludin proteins, in the cell junctions, in the cytoskeleton of the Sertoli cells, and as an increase in the permeability of the hematotesticular barrier.
Despite a lack of data related to effects of glycerol in fish, analogous to the mammal model, the hematotesticular barrier interconnects the Sertoli cells by continuous occlusion junctions, dividing each seminiferous tube into two distinct functional compartments, the basal and adluminal compartments. The basal compartment comprises

Table 7

Chemical composition of different organs/tissues of Nile tilapia males (O. niloticus) fed pelletized diets with different levels of crude glycerin.

\begin{tabular}{|c|c|c|c|c|c|c|}
\hline \multirow[t]{2}{*}{$\operatorname{VAR}(\%)$} & \multicolumn{5}{|c|}{ Inclusion level of crude glycerin (\%) } & \multirow[t]{2}{*}{$p$} \\
\hline & 0 & 4 & 8 & 12 & 16 & \\
\hline \multicolumn{7}{|l|}{ Muscle } \\
\hline $\mathrm{CP}$ & $15.97 \pm 1.11^{\mathrm{b}}$ & $12.09 \pm 1.80^{c}$ & $25.32 \pm 0.89^{\mathrm{a}}$ & $24.32 \pm 0.29^{\mathrm{a}}$ & $21.75 \pm 3.41^{\mathrm{a}}$ & 0.0029 \\
\hline FA & $0.44 \pm 0.66$ & $0.08 \pm 0.07$ & $0.69 \pm 0.98$ & $1.03 \pm 1.49$ & $1.11 \pm 2.14$ & 0.8264 \\
\hline MO & $79.37 \pm 0.28$ & $79.34 \pm 0.61$ & $79.83 \pm 1.10$ & $79.31 \pm 0.25$ & $79.01 \pm 0.90$ & 0.2406 \\
\hline AS & $3.17 \pm 1.04$ & $4.98 \pm 0.73$ & $4.79 \pm 0.55$ & $4.08 \pm 0.70$ & $8.12 \pm 7.12$ & 0.2228 \\
\hline \multicolumn{7}{|l|}{ Viscera } \\
\hline $\mathrm{CP}$ & $10.55 \pm 1.07$ & $10.55 \pm 2.40$ & $10.36 \pm 1.14$ & $10.21 \pm 1.25$ & $11.34 \pm 2.24$ & 0.7440 \\
\hline FA & $0.33 \pm 0.13$ & $0.43 \pm 0.32$ & $0.51 \pm 0.19$ & $0.42 \pm 0.30$ & $0.62 \pm 0.54$ & 0.8542 \\
\hline \multicolumn{7}{|l|}{ Gonads } \\
\hline $\mathrm{CP}$ & $11.55 \pm 1.00^{\mathrm{b}}$ & $14.77 \pm 5.06^{a}$ & $15.96 \pm 1.19^{\mathrm{a}}$ & $14.15 \pm 3.12^{\mathrm{a}}$ & $16.91 \pm 1.30^{\mathrm{a}}$ & 0.0404 \\
\hline \multicolumn{7}{|l|}{ Liver } \\
\hline FA & $2.59 \pm 1.33$ & $2.48 \pm 1.17$ & $2.85 \pm 0.17$ & $3.23 \pm 2.25$ & $2.35 \pm 0.68$ & 0.9135 \\
\hline
\end{tabular}

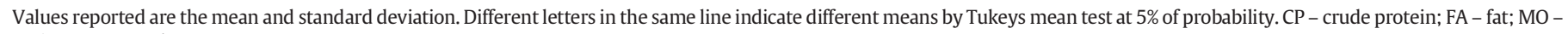
moisture; AS - ash.

Different letters in the same line indicate different means by Tukey's mean test at $5 \%$ of probability. 
spermatogonia, whereas the adluminal compartment comprises the cells in successive spermatogenic differentiation. The barrier in this case provides a micro-environment for spermatogenic differentiation and protects the germinative cells in an advanced stage of development against harmful agents or against cells of the immune system (Junqueira and Carneiro, 2013). It may be, therefore, that glycerol from the diet increased the permeability of the hematotesticular barrier, causing cell disorder resulting in impairment of spermatogenesis.

The negative effects of glycerol were also reported in mammals treated with $10 \%$ glycerol solution applied either orally or by intratesticular injection. These treatments suppressed spermatogenesis in rats (Wiebe and Barr, 1984; Igdoura and Wiebe, 1994) and monkeys (Wiebe et al., 1989). Damage to spermatogenesis may be related to inhibition of the mitochondrial activity of spermatogonia and spermatids due to the action of glycerol-3-phosphate dehydrogenase (Weitzel et al., 2003), which is basic for mammal spermatozoids because they produce ATP (Peña et al., 2009).

In testicle histology, the presence of different cysts within the differentiation process in all treatments reveals that males were mature for spermiation. However, the negative effects of crude glycerin in the diets were evident in the spermatogenesis effects. Information on the effects of crude glycerin in the germinative epithelium of fish is scarce. Studies in mammals report a significant decrease in the height of the germinative epithelium in glycerol-treated rats (Igdoura and Wiebe, 1994), whereas crude glycerin failed to alter the height of the germinative epithelium in sheep (Gomes, 2009).

Results of the gonadosomatic index corroborate the histological outcomes in the testicles and support the hypothesis that all of the animals were at the same stage of gonadal maturity. This index is employed to monitor gametogenesis progression in fish (Barcellos et al., 2001) and is related to the gonadal maturation peak (Barcellos et al., 2002), where testicular volume increase is caused by the proliferation of the germination epithelium (Schulz et al., 2010).

Glycerol derived from diets containing crude glycerin may also interfere with glycemic levels in fish, because it is an intermediary metabolic factor in gluconeogenesis (Lin, 1977), which directly affects the energetic metabolism and thus the growth of fish (Gonçalves et al., 2015). Glucose in vertebrates is an important metabolic fuel, and several mechanisms provide a constant supply to the glucose-dependent tissues where liver glycogen serves as the glucose reserve (Thrall et al., 2015).

Decreases in plasma glucose levels have been reported in young Nile tilapia when fed diet containing crude glycerin (Moesch, 2014). A similar glycemic behavior occurred in our tilapia broodstock, likely related to the diet's carbohydrate content (Thrall et al., 2015). In fact, increased glycerin in diets was due to the reduction in corn levels and, consequently, starch amounts. Furthermore, starch deficits may have triggered the animals to synthetize glucose from the glycerol in the diet by hepatic gluconeogenesis (Nelson and Cox, 2011) with the subsequent increase in energy demand.

The hepatosomatic index is a highly relevant parameter for directly evaluating liver conditions and liver metabolism, coupled with establishing conditions of glycogen reserve. The hepatosomatic index of tilapia broodstock increased in proportion to the inclusion of glycerol in the diets, similar to the findings in juvenile specimens of Ictalurus punctatus fed diets with 15 and 20\% crude glycerin (Li et al., 2010). Assays with rats indicate that the effect of dietary glycerol on the increase in the hepatosomatic index may be related to the increase in the activity of lipogenic enzymes in the hepatocytes (Lin, 1977). Although the current study did not aim to evaluate these enzymes, the assessment of the histological parameters of the hepatic tissue suggest that there was no strong relationship between diet and the accumulation of lipids in the hepatocytes. However, special attention should be given to fat accumulation in hepatocytes. In fact, several authors have registered the occurrence of vacuolization in hepatocytes and even clinical conditions of steatosis due to the diet (Bombardelli et al., 2010; Bolla et al., 2011;
Tessaro et al., 2012). In the medium and long term, hepatic changes may cause reproductive losses and even death.

Despite the direct relationship between spermatic concentration and fecundity and the numerical decrease in spermatozoid amounts per milliliter, individual variation in males may have caused the lack of diet effects on spermatic concentration. Glycerol in the diet does not seem to have affected the final processes of spermatogenesis specifically related to the formation of the spermatozoid tails and spermatic capacitation (Schulz et al., 2010) because the parameters involved in spermatic movements, such as seminal $\mathrm{pH}$, motility, activation time, spermatic velocity and normality were not affected by diet.

The plasmatic concentration of triglycerides is related to the capacity of storage, nutritional condition, glycemic state, mobilization from several tissues and its use as an energy source. Because this parameter was not changed in the broodstock, it may be possible that the glycerol derived from diets containing crude glycerin was an adequate energy source, and consequently, failed to alter lipolysis in the adipocytes (Costa et al., 2015).

Furthermore, due to the direct relationship between plasma calcium levels and plasmatic protein rates (Thrall et al., 2015), it may be suggested that the diets did not affect the health of the tilapia broodstock (Gonçalves et al., 2015).

Diets were not expected to influence broodstock growth (Bombardelli et al., 2010) because previous research has shown that the inclusion of up to $10 \%$ crude glycerin in diets did not interfere with the growth of juvenile tilapia (Neu et al., 2012). Li et al. (2010) also stated that crude glycerin in the diet of Ictalurus punctatus juveniles did not affect growth. Furthermore, because the animals were reproductively active, high levels of apparent feed conversion (between 1.91 and $2.21 \mathrm{~g} \cdot \mathrm{g}^{-1}$ ) in tilapia broodstock are justified (Bombardelli et al., 2010).

Although the broodstock did not undergo changes in growth, fish diets with glycerin increased crude protein rates in the muscles and in the testicles. A similar increase in protein deposition in the muscles was also found in tilapia juveniles fed diets containing crude glycerin, which may be related to economy of glycogenic amino acids (Gonçalves et al., 2015) and to the possible influence of glycerin in the diets on the enzymatic activity of glutamate dehydrogenase (Bernardino et al., 2014). The glycerin in the diets may have similarly affected the protein metabolism related to the testicles. Despite such evidence, this is only preliminary research, and little information about this theme is available in the literature. Therefore, further studies need to be completed to clarify the mechanisms involved in the effects of dietary glycerin on protein and energy metabolism, and particularly on the spermatogenesis of Nile tilapia. Further studies are needed to evaluate effects of dietary glycerin on reproductive success of Nile tilapia broodstock.

\section{Conclusion}

Results show that crude glycerin does not impair growth, although at any inclusion level, it damages the spermatogenesis process and jeopardizes the sperm characteristics in Nile tilapia males.

\section{Acknowledgements}

The authors would like to thank the Conselho Nacional de Desenvolvimento Científico e Tecnológico, Process CNPq \# 485664/ 2011-9 (National Council for Scientific and Technological Development - CNPq) and the Fundação Araucária de Apoio ao Desenvolvimento Científico e Tecnológico do Paraná, Process \# 15924 (Fundação Araucária for Scientific Support and Technological Development in the Paraná State), which granted the research funds. The authors also thank Dra. Irani Quagio Grassiotto and her team for their support with histological analyses. 


\section{References}

Adames, M.S., Toledo, C.P.R., Neumann, G., Buzzi, A.H., Buratto, C.N., Piana, P.A., Bombardelli, R.A., 2015. Optimization of the sperm: oocyte ratio and sperm economy in the artificial reproduction of Rhamdia quelen using fructose as a sperm motility modulator. Anim. Reprod. Sci. 161, 119-128.

Ayoub, M., Abdullah, A.Z., 2012. Critical review on the current scenario and significance of crude glycerol resulting from biodiesel industry towards more sustainable renewable energy industry. Renew Sust. Energy. Rev. 16, 2671-2686.

Barcellos, L.J.G., Woehl, V.M., Wassermann, G.F., Quevedo, R.M., Ittzés, I., Krieger, M.H. 2001. Plasma levels of cortisol and glucose in response to capture and tank transference in Rhamdia quelen, a south American catfish. Aquac. Res. 32, 121-123.

Barcellos, L.J.G., Wassermann, G.F., Scott, A.P., Woehl, V.M., Quevedo, R.M., Ittzés, I., Krieger, M.H., Lulhier, F., 2002. Plasma steroid concentrations in relation to the reproductive cycle of cultured male Rhamdia quelen. J. Fish Biol. 61, 751-763.

Berenchtein, B., Costa, L.B., Braz, D.B., Almeida, V.V., Panhoza, M.L., Miyada, V.S., 2010. Utilização de glicerol na dieta de suínos em crescimento e terminação. R. Bras. Zootec. 39, 1491-1496.

Bernardino, V.M.P., Rodrigues, P.B., Naves, L.P., Zangeroimo, M.G., Alvarenga, R.R., Rosa P.V., Santos, L.M., Teixeira, L.V., 2014. Activity of glutamate dehydrogenase and protein content in the breast of broilers fed diets containing different sources and levels of glycerine. J. Anim. Physiol. Anim. Nutr. 98, 559-568.

Bhujel, R.C., 2000. A review of strategies for the management of Nile tilapia (Oreochromis niloticus) broodfish in seed production systems, especially hapa-based systems. Aquaculture 181, 37-59.

Bolla, S., Nicolaisen, O., Amin, A., 2011. Liver alterations induced by long term feeding on commercial diets in Atlantic halibut (Hippoglossus hippoglossus L.) females. Histological and biochemical aspects. Aquaculture 312, 117-125.

Bombardelli, R.A., Hayashi, C., Natali, M.R.M., Sanches, E.A., Piana, P.A., 2009. Desempenho reprodutivo e zootécnico e deposição de lipídios nos hepatócitos de fêmeas de tilápia-do-nilo alimentadas com rações de diversos níveis energéticos. R. Bras. Zootec. 38, 1391-1399.

Bombardelli, R.A., Hayashi, C., Natali, M.R.M., Sanches, E.A., Piana, P.A., 2010. Níveis de energia digestível sobre os desempenhos reprodutivo e zootécnico e a deposição de lipídios nos hepatócitos de machos de tilápia-do-nilo. R. Bras. Zootec. 39, 941-949.

Bromage, N., 1995. Broodstcok management and seed quality - general considerations. In: Bromage, N.R., Roberts, R.J. (Eds.), Broodstock Management and Egg and Larval Quality. Blackwell Science Ltd., London, pp. 1-25.

Brown-Peterson, N.J., Wyanski, D.M., Saborido-Rey, F., Macewicz, B.J., Lowerre-Barbieri, S.K., 2011. A standardized terminology for describing reproductive development in fishes. Mar. Coast. Fish. Dyn. Manage. Ecosyst. Sci. Adv. Search 3, 52-70.

Caballero, M.J., Izquierdo, M.S., Kjorsvik, E., Fernández, A.J., Rosenlund, G., 2004. Histological alterations in the liver of sea bream, Sparus aurata L., caused by short- or longterm feeding with vegetable oils. Recovery of normal morphology after feeding fish oil as the sole lipid source. J. Fish Dis. 27, 531-541.

Costa, D.V., Paulino, R.R., Okamura, D., Oliveira, M.M., Rosa, P.V., 2015. Growth and energy metabolism of Nile tilápia juveniles fed glycerol. Pesqui. Agropec. Bras. 50, 347-354

El-Sayed, A.-F.M., 2006. Tilapia Culture. CABI, Massachusetts.

El-Sayed, A.-F.M., Mansour, C.R., Ezzat, A.A., 2005. Effects of dietary lipid source on spawning performance of Nile tilapia (Oreochromis niloticus) broodstock reared at different water salinities. Aquaculture 248, 187-196.

Food and Agriculture Organization Of The United Nations - FAO, 2014F. The State of World Fisheries and Aquaculture - Opportunities and Challenges. Food and Agricultural Organization, Rome.

Gomes, M.A.B., 2009. Parâmetros produtivos e reprodutivos de ovinos suplementados com glicerina da produção de biodiesel. Dissertação de mestrado apresentada ao Programa de Pós-Graduação em Zootecnia. Universidade Estadual de Maringá, Maringá.

Gonçalves, L.U., Cerozi, B.S., Silva, T.S.C., Zanon, R.B., Cyrino, J.E.P., 2015. Crude glycerin as dietary energy source for Nile tilapia. Aquaculture 437, 230-234.

Hardy, R.W., 1999. Collaborative opportunities between fish nutrition and other disciplines in aquaculture: an overview. Aquaculture 177, 217-230.

Boscolo, W.R., Hayashi, C., Meurer, F., 2002. Digestibilidade aparente da energia nutrientes de alimentos convencionais e alternativos para a tilápia do Nilo (Oreochromis niloticus, L.). R. Bras. Zootec. 13, 539-545.

Igdoura, S.A., Wiebe, J.P., 1994. Suppression of spermatogenesis by low-level glycerol treatment. J. Androl. 15, 234-243.

Izquierdo, M.S., Fernandez-Palacios, H., Tacon, A.G.J., 2001. Effect of broodstock nutrition on reproductive performance of fish. Aquaculture 197, 25-42.

Junqueira, L.C.U., Carneiro, J., 2013. Histologia Básica: texto e atlas. 12th ed. Guanabara Koogan, Rio de Janeiro.

Kanuga, M.K., Drew, R.E., Wilson-Leedy, J.G., Ingermann, R.L., 2012. Subpopulation distribution of motile sperm relative to activation medium in steelhead (Oncorhynchus mykiss). Theriogenology 77, 916-925.

Khara, H., Baradaran, S.N., Hadiseh, D., Rahbar, M., Ahmadnejad, M., Khodadoost, A., 2012. The effect of cations on sperm motility performance and fertilizing ability of silver carp Hypophtalmychtis molitrix. Acta Vet. Beograd 62, 599-609.

Kroupa, L., Suchý, P., Straková, E., Herzig, I., 2011. Glycerol as source of energy in broiler chicken fattening. Acta Vet. Brno 80, 157-164

Li, M.H., Minchew, C.D., Oberle, D.F., Robinson, E.H., 2010. Evaluation of glycerol from biodiesel production as a feed ingredient for channel catfish, Ictalurus punctatus. J. World Aquacult. Soc. 41, 130-136.

Lin, E.C.C., 1977. Glycerol utilization and its regulation in mammals. Annu. Rev. Biochem. 46, 765-795.
Macintosch, D.J., Little, D.C., 1995. Nile tilapia (Oreochromis niloticus). In: Bromage, N.R., Roberts, R.J. (Eds.), Broodstock Management and Egg and Larval Quality. Blackwell Science Ltd., London, pp. 277-320.

Mataveli, M., Moraes, G.V., Streit-Junior, D.P., Ribeiro, R.P., Gasparino, E., 2007. Avaliação da qualidade do sêmen de tilápia-do-Nilo (Oreochromis niloticus), linhagem chitralada, suplementada com diferentes concentrações de Vitamina C. Bol. Inst. Pesca 33, 1-7.

Meurer, F., Hayashi, C., Boscolo, W.R., 2003. Digestibilidade aparente de alguns alimentos protéicos pela tilápia do Nilo (Oreochromis niloticus). R. Bras. Zootec. 32, 1801-1809.

Meurer, F., Franzen, A., Piovesan, P., Rossato, K.A., Santos, L.D., 2012. Apparent energy digestibility of glycerol from biodiesel production for Nile tilapia (Oreochromis niloticus, Linnaeus 1758). Aquac. Res. 43, 1734-1737.

Mizubuti, I.Y., Pinto, A.P.P., Ramos, B.M.O., Pereira, E.S., 2009. Métodos laboratoriais de Avaliação de Alimentos para Animais. first ed. EDUEL, Londrina.

Moesch, A., 2014. Glicerol bruto, derivado da produção do biodiesel, em rações peletizadas para diferentes fases de tilápia do Nilo. Dissertação de mestrado apresentada ao Programa de Pós-Graduação em Aquicultura e Desenvolvimento Sustentável. Universidade Federal do Paraná, Palotina.

Nelson, D.L., Cox, M.M., 2011. Princípios de bioquímica de Lehninger. 5th ed. Artmed, Porto Alegre.

Neu, D.H., Furuya, W.M., Yamashiro, D., Bittencourt, F., Moro, E.B., Fernandes, D.R.A., Boscolo, W.R., Feiden, A., 2012. Glycerol inclusion in the diet of Nile tilapia (Oreochromis niloticus) juveniles. Aquacult. Nutr. 19, 211-217.

Ng, W.K., Wang, Y., 2011. Inclusion of crude palm oil in the broodstock diets of female Nile tilapia, Oreochromis niloticus, resulted in enhanced reproductive performance compared to broodfish fed diets with added fish oil or linseed oil. Aquaculture 314, 122-131.

Oliveira, M.M., Ribeiro, T., Orlando, T.M., Oliveira, D.G.S., Drumond, M.M., Freitas, R.T.F., Rosa, P.V., 2014. Effects crude protein levels on female Nile tilapia (Oreochromis niloticus) reproductive performance parameters. Anim. Reprod. Sci. 150, 62-69.

Peña, F.J., Martinez, H.R., Tapia, J.A., Ferrusola, C.O., Fernández, L.G., Garcia, B.M., 2009. Mitochondria in mammalian sperm physiology and pathology: a review. Reprod. Domestic. Anim. 44, 345-349.

Putstowka, C., McNiven, M.A., Richardson, G.F., Lall, S.P., 2000. Source of dietary lipid affects sperm plasma membrane integrity and fertility in rainbow trout Oncorhyncgus mykys (Walbaum) after cryopreservation. Aquac. Res. 31, 297-305.

Rurangwa, E., Kime, D.E., Ollevier, F., Nash, J.P., 2004. The measurement of sperm motility and factors affecting sperm quality in cultured fish. Aquaculture 234, 1-28.

Sanches, E.A., Marcos, R.M., Okawara, R.Y., Caneppele, D., Bombardelli, R.A., Romagosa, E., 2013. Sperm motility parameters for Steindachneridion parahybae based on opensource software. J. Appl. Ichthyol. 29, 1114-1122.

Schulz, R., De Franca, L., Lareyre, J., LeGac, F., Chiarini-Garcia, H., Nobrega, R.H., Miura, T., 2010. Spermatogenesis in fish. Gen. Comp. Endocrinol. 165, 390-411.

Shields, M.C., Van Heugten, E., Lin, X., Odle, J., Stark, C.S., 2011. Evaluation of the nutritional value of glycerol for nursery pigs. J. Anim. Sci. 89, 2145-2153.

Siddiqui, A.Q., Al-Hafedh, Y.S., Ali, S.A., 1998. Effect of dietary protein level on the reproductive performance of Nile tilapia, Oreochromis niloticus (L.). Aquac. Res. 29, 349-358.

Swiatkiewicz, S., Koreleski, J., 2009. Effect of crude glycerin level in the diet of laying hens on egg performance and nutrient utilization. Poult. Sci. 88, 615-619.

Tacon, P., Ndiaye, P., Cauty, C., Le Menn, F., Jalabert, B., 1996. Relationships between the expression of maternal behavior and ovarian development in the mouthbrooding cichlid fish Oreochromis niloticus. Aquaculture 146, 261-275.

Tavares-Dias, M., Moraes, F.R., 2004. Hematologia dos peixes teleósteos. FMRP-USP, Ribeirão Preto.

Tessaro, L., Toledo, C.P.R., Neumann, G., Krause, R.A., Meurer, F., Natali, M.R.M., Bombardelli, RA, 2012. Growth and reproductive characteristics of Rhamdia quelen males fed on different digestible energy levels in the reproductive phase. Aquaculture 326, 74-80.

Thrall, M.A., Weiser, G., Allison, R.W., Campbell, T.W., 2015. Hematologia e bioquímica clínica veterinária. 2nd ed. Guanabara Koogan, Rio de Janeiro.

Tyler, C.R., Sumpter, J.P., 1996. Oocyte growth and development in teleosts. Rev. Fish biol. Fisher. 6, 287-318.

Vazzoler, A.E.A.M., 1996. Biologia da reprodução de peixes teleósteos: teoria e prática. 1st ed. EDUEM, Maringá.

Watanabe, T., Vassalo-Agius, R., 2003. Broodstock nutrition research on marine finfish in Japan. Aquaculture 227, 35-61.

Watanabe, W.O., Losordo, T.M., Hanley, F., 2002. Tilapia production systems in the Americas: technological advances, trends and challenges. Rev. Fish. Sci. 10, 465-498.

Weitzel, J.M., Shiryaeva, N.B., Middendorff, R., Balvers, M., Radtke, C., Ivell, R., Seitz, H.S., 2003. Testis - specific expression of rat mitochondrial glycerol-3-phosphate dehydrogenase in haploid male germ cells. Biol. Reprod. 68, 699-707.

Wiebe, J.P., Barr, K.J., 1984. Suppression of spermatogenesis without inhibition of steroidogenesis by a 1,2,3-trihydroxypropane solution. Life Sci. 34, 1747-1754.

Wiebe, J.P., Barr, K.J., Buckingham, K.D., 1989. Sustained azoospermia in squirrel monkey, Saimiri sciureus, resulting from a single intratesticular glycerol injection. Contraception 39, 447-457.

Wiebe, J.P., Kowalik, A., Gallardi, R.L., Egeler, O., Clubb, B.H., 2000. Glycerol disrupts tight junction associated actin microfilaments, occluding, and microtubules in sertoli cells. J. Androl. 21, 625-635.

Wirtz, S., Steinmann, P., 2006. Sperm characteristics in perch Perca fluviatilis L. J. Fish Biol. 68, 1896-1902. 